\title{
THERMOGRAPHIC CAMERA APPLICATION FOR GALVANIC CORROSION DETECTION
}

\author{
Ferenc HARASZTI \\ Óbuda University, Bánki Donát Faculty of Mechanical and Safety Engineering Material Science Department, \\ Budapest, Hungary, haraszti.ferenc@bgk.uni-obuda.hu
}

\begin{abstract}
The components of electric connections have a tenancy to corrosion. We can observe a galvanic corrosion process hazard in case of the contact between different electron potential metals. This corrosion process impairs the mechanical properties and the connection through increased resistance. The conduction parameters decrease in some parts that are under high load because of the rise in heat. This heat effect can be undetectable. By thermographic camera experiments, we can reveal this irregularity at an early stage. In this work, we present this investigation and the associated problems.
\end{abstract}

Keywords: galvanic corrosion, thermographic camera, current, balckbody, emission.

\section{Introduction}

Electric connection constructions have different metal elements with different mechanical properties. We can observe different types of corrosion for different materials. Between the different metals, a corrosion reaction can occur if we have different electrode potentials. This kind of the corrosion is known as galvanic corrosion. This corrosion is a chemical corrosion that occurs between two different metals in the presence of a liquid electrolyte. The name of this corrosion type came from the name of the chemical process, because two electrochemically different metals and the electrolyte create a galvanic cell. The low electrode potential metal dissolves in the electrolyte and the surface is damaged. This reaction effect impairs electric current transfer because it increases the momentary resistance [1-3].

\section{Theoretical basis of the investigation}

\subsection{Electrical contact testing possibilities}

In our modern age, we cannot live without electric current; ensuring a continuous current supply is a critical infrastructure requirement [4]. The metal connection bounding lifetime is very difficult to calculate because of the corrosion phenomenon and is not calculable easily. This electri- cal contact problem can cause severe problems in industrial and personal life too. Prediction of the electric device bounding lifetime is a challenge in the current century. The simplest tests are visual inspection and temperature measurement. The bounding impairment causes a temperature increase. The temperature measurement is not easy by the traditional measuring methods, since for this process we switch off the current. The power interruption can cause impairment in industries and homes. Thanks to modern technology innovations, we can find new devices for safe and precise temperature detection.

\subsection{Thermographic camera usability}

Temperature measurement of infrared radiation by thermographic camera depends on the bodies heat effect capabilities. The heat radiation process influences the material heat movement that produces electromagnetic waves. The heat energy emission can be in form of conduction, convection and radiation. The bigger part of the heat emission for other bodies can be reflection or transmission. A completely black body absorbs all radiation. The sample that reflects all radiation is a completely reflective body. The one which lets through all radiation is a transparent body. Heat radiation, like electromagnetic wave transfer 
does not require any media. The heat radiation fundamental law is the Stefan-Boltzmann law (1) [5]. The emissivity constant depends entirely on the material of the object and is capped at 1 for an ideal black body [5].

$$
P_{\text {Rad }}=e \cdot \sigma \cdot A_{s} \cdot T^{4}[\mathrm{~J}]
$$

where:

$\mathrm{T}[\mathrm{K}]$ - temperature,

$\mathrm{P}_{\text {Rad }}[\mathrm{J}]$ - radiated energy,

e [-] - emissivity of the object,

$\mathrm{A}_{\mathrm{s}}\left[\mathrm{m}^{2}\right]$-surface area,

$\sigma=5,6710^{-8}\left[\mathrm{~J} / \mathrm{m}^{2} \mathrm{~K}^{4}\right]$ - Stefan-Boltzmann constant.

Even when $\mathrm{e}, \mathrm{A}_{\mathrm{s}}$ and $\sigma$ are constant, the equation is simple (2):

$$
P=\sigma \cdot T^{4}[\mathrm{~J}]
$$

By this law the radiation of the black body on $\mathrm{T}$ temperature for unit area and during unit time is proportional with $\mathrm{T}^{4}$. In an ideal situation, the black body is able to absorb and emit all heat energy. It is only a model. Different materials can emit different energy. In the case of measurement, the black body-like material gives exact results. In the case of different materials, we need to correct the result.

\section{Experiments}

\subsection{Used samples and preparation}

Very common in the case of electrical bounding is the copper and steel contact. To investigate the galvanic corrosion phenomenon, we constructed a bounding for our laboratory simulation test. The measured resistance before corrosion was $0,01 \Omega$. Before the test we treated this bounding by surface preparation and corrosion load effect in $3 \%$ salt spray for 168 hours oat $40^{\circ} \mathrm{C}$ temperature Figures 1-3. shows the used samples.

\subsection{Experiment process}

Figure 4. shows the experimental setup with integrated thermographic camera (TESTO 880). In the case of the heating device's different position, the used power is also different. The electric current transfers across the prepared bounding, which causes a measurable heat because its resistance changes during the treatment preparation (5600 $\Omega$ ). The thermographic camera supports a safe and exact heat measuring process [6]. In this experiment, we measured the temperature of the bounding as a function of the electric current change.

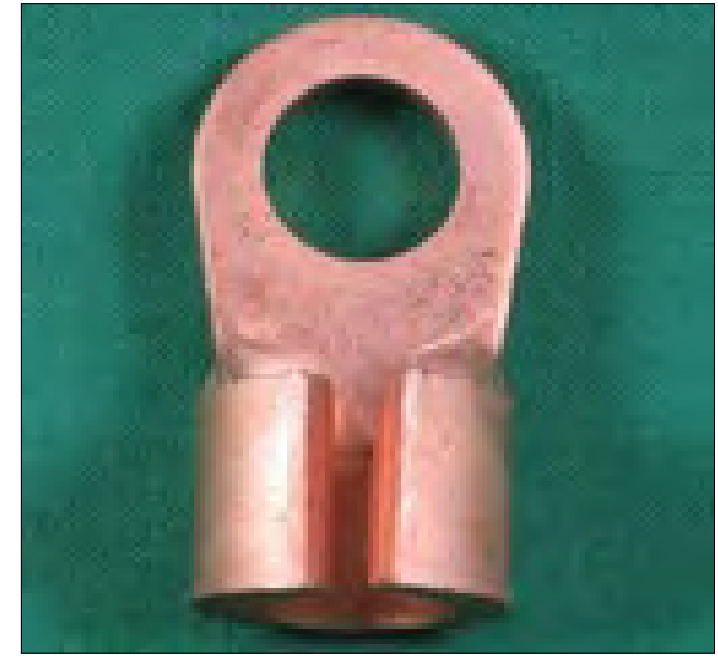

Figure 1. Copper sample

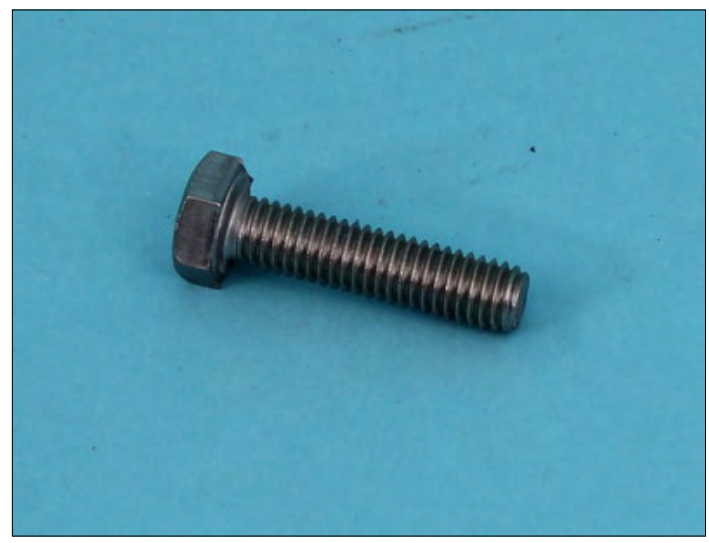

Figure 2. Steel screw

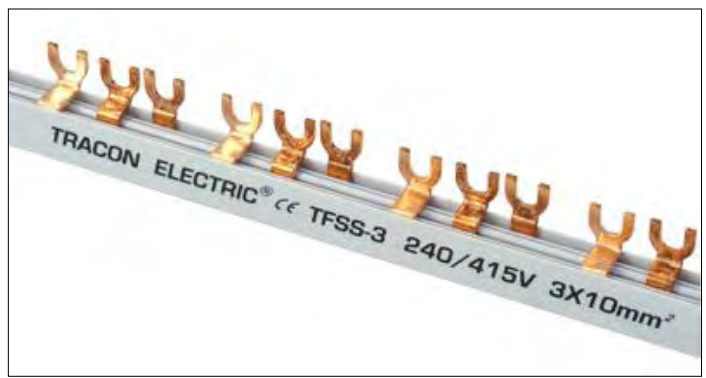

Figure 3. Single-phase comb busbar max. $63 \mathrm{~A}$

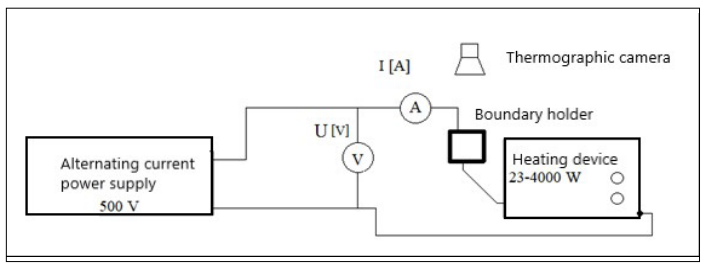

Figure 4. Experimental setup 
The thermographic camera registered result is shown in Figures 6-7.

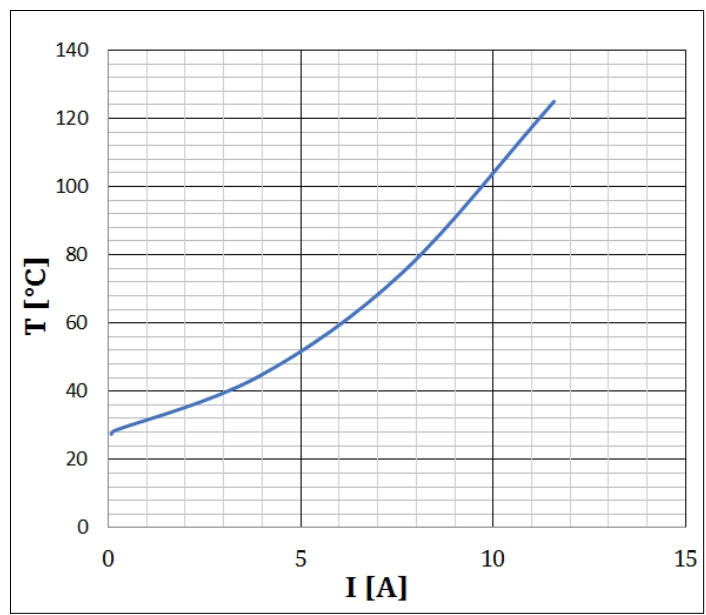

Figure 5. The relationship between current and temperature

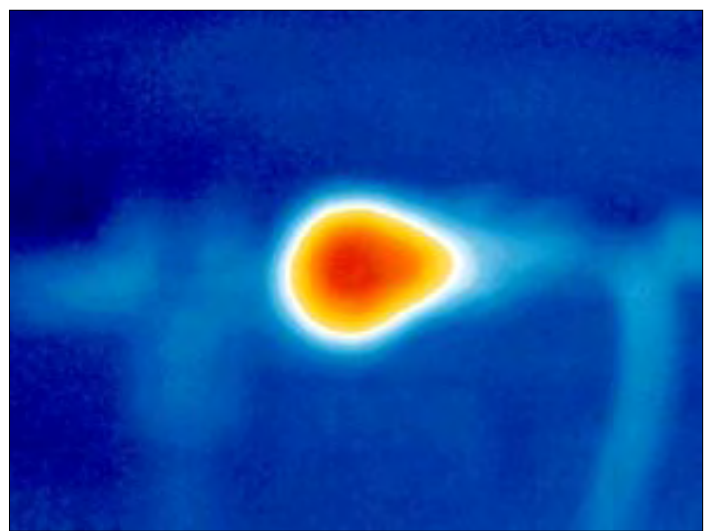

Figure 6. Image of the tested boundingat $44,3{ }^{\circ} \mathrm{C}$

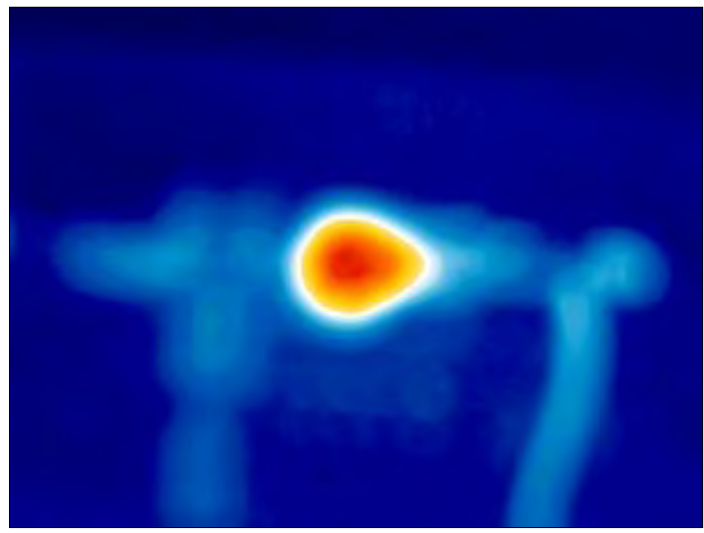

Figure 7. Image of the tested bounding at $125^{\circ} \mathrm{C}$
Table 1. Experimental results

\begin{tabular}{|c|c|c|}
\hline Number & Current [A] & Temperature $\left[{ }^{\circ} \mathbf{C}\right]$ \\
\hline 1 & 0 & 27.2 \\
\hline 2 & 0.08 & 27.4 \\
\hline 3 & 0.15 & 28.4 \\
\hline 4 & 3.9 & 44.3 \\
\hline 5 & 7.66 & 75 \\
\hline 6 & 11.58 & 125 \\
\hline
\end{tabular}

\subsection{Experiment results}

Table 1. shows the experimental results, which shows a relationship between the change in temperature and the current. High-density electric power causes heat. We supposed, based on equation (3), a relationship between the temperature and the power. Equation (3) where $\mathrm{P}[\mathrm{W}]$ is the electric power, I [A] is the electric current, U [V] is the voltage:

$$
P=U \cdot I \quad[\mathrm{~W}]
$$

Using the fundamental equation, where $\mathrm{R}$ is the resistance in Ohms (4):

$$
U=R \cdot I \quad[\mathrm{~V}]
$$

Equation (3) was modified according to equation (4) to give (5):

$$
P=R \cdot I^{2} \quad[\mathrm{~W}]
$$

The resulting equation (5) shows the relationship between the power (P) and the current (I). From this equation, we can see that the electric power in our experiment and the heat energy has a square relationship with current (Figure 5.).

\section{Conclusions}

The experiment results supported our hypothesis concerning the relationship between the change in temperature and the current. The reason for this relationship is that the electrical energy transforms to heat energy, according to Newton's energy conservation law.

The temperature of the used bounding changed during the experiment. Based on this result we can conclude that in real applications we can detect the same phenomenon.

The galvanic corrosion causes a change of resistance. The galvanic corrosion results an extremely high resistance in the bounding.

The changing temperature is measurable and it can be detected by a thermographic camera device. The thermographic camera is very useful 
because it can measure the temperature without any contact, therefore the measuring process is safe.

\section{References}

[1] Haraszti F.: The bases of corrosion's investigation. In: A XXI. Fiatal müszakiak tudományos ülésszak előadásai. Proceedings of the 21th international scientific conference of youngth engineers, Kolozsvár/Cluj, Románia, Müszaki Tudományos Közlemények 5. (2016) 185-188. https://eda.eme.ro/handle/10598/29058

[2] Haraszti F.: Corrosion investigation of steel smaples. In: A XXI. Fiatal múszakiak tudományos ülésszak előadásai. Proceedings of the 21th international scientific conference of youngth engineers, Kolozsvár/Cluj, Románia, Müszaki Tudományos Közlemények 5. (2016) 189-192. https://eda.eme.ro/handle/10598/29057
[3] Kovács-C. T., Völgyi B., Sikari-Nágl I.: Galvanic corrosion behavirour testing in case of aluminum and steel couple. In: Fiatal műszakiak tudományos ülésszaka XVIII., Kolozsvár/Cluj, Románia, Műszaki Tudományos Füzetek 2013. 201-204. https://eda.eme.ro/handle/10598/26880

[4] Wellons M.: The Stefan-Boltzmann Law. Physics Department, The College of Wooster, Wooster, Ohio 44691, USA, May 9, 2007.

[5] Kittel C., Kroemer H.: Thermal Physics (W. H. Freeman and Company, 1980) ASTM Standard Practice in A 262 for Detecting Susceptibility to Intergranular Corrosion in Austenitic Stainless Steels.

[6] www.termokamera.hu, www.globalfocus.hu (accessed on: $22^{\text {nd }}$ January 2019. )

[7] Budó Á.: Kísérleti Fizika II. Tankönyvkiadó, Budapest, 1971. 